\title{
Atrioventricular Conduction in Children of Women with Systemic Lupus Erythematosus
}

\author{
Monica Martin Goble, MD, Macdonald Dick II, MD, W. Joseph McCune, MD, \\ Janet Ellsworth, MD, Donita B. Sullivan, MD, and Aaron M. Stern, MD
}

\begin{abstract}
The neonatal lupus syndrome consists of transient cutaneous lupus lesions or pormanent congenital complete heart block (or hepatic fibrosis), or both, in infants bom to mothers with systemic lupus erythematosus (SLE). The frequency of conduction abnomalities was examined in 86 offespring of 53 women affected by SLE. Electrocardiograns from the offspring demonstrated normal sinus inythm in 84 of 86 offepring. The PR interval was nomal for age (<95th percentile) in 82 offepring and normal for heart rate in 81. Three children had a PR interval >95th percentile (i.e., first-degree heart block) for both age and heart rate. The PR interval of the other 6 subjects with first-degree heart block for age or heart rate ( $\geq 95$ th percentile) was $\leq 0.18$ second. In contrast, using a rank assignment of PR intervals in relation to hoart rate and age derived from published standards, grouped data indicated that heart rate adfusted for age was greater and PR interval adjusted for heart rate longer in offepring of mothers who had the onset of SLE before or during pregnancy than in the normal population; this observation did not hold for offepring whose mothers developed SLE after the pregnancy. These findines indicate that offepring of mothers with SLE, even in the absence of an abnomal electrocandiogram, may have experienced a matemal intemal environment that produces subclinical changes in atrioventricular conduction. However, newboms with a normal pulse rate are unlikely to have significant abnomalities in atrioventricular conduction and do not need screening electrocardiograms at birth.
\end{abstract}

(Am J Cardiol 1993;71:94-98)

From the Divisions of Pediatric Cardiology and Pediatric Rheumatology, Department of Pediatrics, and the Division of Rheumatology, Department of Internal Medicine, University of Michigan, Ann Arbor, Michigan. Dr. Goble is now at the Medical College of Virginia, Richmond, Virginia. This study was supported in part by Grant M01RR00042 from the National Institutes of Health, Bethesda, Maryland. Manuscript received May 26, 1992; revised manuscript received and accepted July 27, 1992.

Address for reprints: Macdonald Dick II, MD, F1310 Box 0204, C.S. Mott Children's Hospital, University of Michigan Medical Center, 1500 East Medical Center Drive, Ann Arbor, Michigan 48109-0204.
$\mathrm{T}$ The neonatal lupus syndrome consists of transient cutaneous lupus lesions or permanent congenital complete heart block (or hepatic fibrosis), or both, occurring in a small percentage of infants born to mothers with systemic lupus erythematosus (SLE). The prevalence of connective tissue disease in mothers of babies with congenital complete heart block ranges from 33 to $64 \% .^{1,2}$ Half of these women are symptomatic; the other half have only serologic evidence of connective tissue disease. ${ }^{3}$ In symptomatic mothers, SLE is the usual underlying disorder, but Sjogren syndrome, rheumatoid arthritis and undifferentiated connective tissue disease have also been found. ${ }^{2,4,5}$ In 1 study, the relation between maternal high-titer antibody and congenital complete heart block suggested a possible dose-response effect. ${ }^{6}$ However, the electrocardiograms of all the infants were not reported. Support for a dose-response relation would be increased, if more subtle conduction disturbances were detected by the electrocardiogram. This study examines the frequency of conduction abnormalities in offspring of mothers with SLE by identifying mothers with SLE rather than by identifying affected infants. Our hypothesis is that offspring of mothers with SLE would have a spectrum of conduction disturbances on the resting electrocardiogram ranging from first-degree atrioventricular block to the already recognized congenital complete heart block.

\section{METHODS}

In 1982 and again in 1988, women with SLE (1982 American Rheumatism Association revised criteria for SLE) followed in the Rheumatology Clinic at the University of Michigan were asked at the time of their regularly scheduled appointment if they had ever been pregnant. For each cohort $(1982[\mathrm{n}=32]$ and 1988 $[\mathrm{n}=21]$ ), women with children were later contacted by telephone and asked to participate in the study. Thirty-two of 42 mothers contacted in 1982 and 21 of 22 in 1988 agreed to participate in the study. In all, 84 of 92 living offspring of 53 women were evaluated. Except for 3 siblings who had electrocardiograms obtained at a local hospital, electrocardiograms were recorded on a Cambridge VS-550 electrocardiographic recorder (frequency response, direct current to 100 $\mathrm{Hz}$ ) with a heat writer on paper moving at $50 \mathrm{~mm} / \mathrm{s}$. Consent forms and questionnaires pertaining to the mother's and child's medical history were completed for each offspring. Anti-SSA/Ro and Anti-SSb/La antibody status was available from 25 mothers (18 from 1988, and 7 from 1982). The study protocol, written 
consent forms and questionnaires for both cohorts were similar and were approved by the institutional review board of the University of Michigan.

Electrocardiographic intervals (Table I) (heart rate, and PR, QRS and QT intervals) were measured independently by 2 investigators using a ruler calibrated to $0.5 \mathrm{~mm}$. Because electrocardiographic standards for children have been published, are widely accepted and are constant over time, a contemporary control group was not necessary. We used standards published in 1980 by Davignon et $\mathrm{al}^{7}$ that were derived from data in a population of 2,141 children (age range 0 to 16 years) divided into 12 age groups. Age-dependent PR intervals and QRS duration percentiles, as well as distributions of






\begin{tabular}{|c|c|c|c|c|c|c|c|c|}
\hline \multirow[b]{2}{*}{ Mother } & \multirow[b]{2}{*}{ Ro-Ab } & \multirow[b]{2}{*}{$\mathrm{La}-\mathrm{Ab}$} & \multirow[b]{2}{*}{ Offspring } & \multirow[b]{2}{*}{$\begin{array}{c}\text { Age } \\
\text { (year) }\end{array}$} & \multirow[b]{2}{*}{$\begin{array}{c}\text { HR } \\
\text { (beats/min) }\end{array}$} & \multicolumn{3}{|c|}{$\begin{array}{l}\text { Electrocardiographic } \\
\text { Intervals }\end{array}$} \\
\hline & & & & & & $\begin{array}{c}\text { PR } \\
\text { (ms) }\end{array}$ & $\begin{array}{l}\text { QRS } \\
(\mathrm{ms})\end{array}$ & $\begin{array}{l}\text { QTNC } \\
\text { (ms) }\end{array}$ \\
\hline \multirow[t]{4}{*}{34} & NA & NA & $34 \mathrm{~A}$ & 22 & 60 & 160 & 80 & 360 \\
\hline & NA & NA & $34 \mathrm{~B}$ & 26 & 75 & 180 & 60 & $360^{\star}$ \\
\hline & NA & NA & $34 C$ & 31 & 49 & 160 & 100 & 380 \\
\hline & NA & NA & 340 & 28 & 77 & 140 & 80 & 400 \\
\hline \multirow[t]{2}{*}{35} & NA & NA & $35 A$ & 14 & 75 & 140 & 60 & 360 \\
\hline & NA & NA & $35 B$ & 7 & 80 & 120 & 80 & 360 \\
\hline 36 & NA & NA & 36 & 24 & 74 & 160 & 80 & 400 \\
\hline \multirow[t]{2}{*}{37} & NA & $37 \mathrm{~A}$ & $36 \mathrm{~A}$ & 15 & 75 & 140 & 100 & 370 \\
\hline & & $37 \mathrm{~B}$ & $36 \mathrm{~B}$ & 14 & 75 & 160 & 100 & 330 \\
\hline 38 & NA & NA & 38 & 7 & 72 & 120 & 60 & 300 \\
\hline \multirow[t]{3}{*}{39} & NA & NA & $39 A$ & 33 & 63 & 160 & 80 & 360 \\
\hline & NA & NA & $39 B$ & 30 & 72 & 140 & 80 & 360 \\
\hline & NA & NA & $39 C$ & 24 & 75 & 140 & 90 & 320 \\
\hline 40 & NA & NA & 40 & 7 & 136 & 150 & 80 & 260 \\
\hline \multirow[t]{3}{*}{41} & NA & NA & $41 \mathrm{~A}$ & 20 & 86 & 150 & 70 & 330 \\
\hline & NA & NA & $41 B$ & 23 & 63 & 160 & 60 & 340 \\
\hline & NA & NA & $41 C$ & 25 & 88 & 140 & 50 & 320 \\
\hline 42 & Pos & Neg & 42 & 31 & 75 & 160 & 80 & 370 \\
\hline \multirow[t]{2}{*}{43} & Neg & $\mathrm{Neg}$ & $43 \mathrm{~A}$ & 5 & 88 & 140 & 80 & 340 \\
\hline & $\mathrm{Neg}$ & Neg & $43 B$ & 10 & 88 & 120 & 60 & 340 \\
\hline 11 & NA & $N A$ & 44 & 10 & 100 & 140 & 60 & 320 \\
\hline 45 & NA & NA & 45 & 42 & 75 & 100 & 60 & 370 \\
\hline \multirow[t]{2}{*}{46} & NA & NA & $46 \mathrm{~A}$ & 11 & 70 & 120 & 80 & 380 \\
\hline & NA & NA & $46 \mathrm{~B}$ & 12 & 68 & 120 & 60 & 400 \\
\hline 47 & Pos & $\mathrm{Neg}$ & 47 & 14 & 96 & 140 & 80 & 360 \\
\hline 48 & NA & NA & 48 & 32 & 70 & 150 & 60 & 340 \\
\hline 49 & Pos & $\mathrm{Neg}$ & 49 & 28 & 77 & 140 & 70 & 360 \\
\hline 50 & NA & NA & 50 & 12 & 114 & 160 & 60 & 310 \\
\hline \multirow[t]{2}{*}{51} & NA & NA & $51 A$ & 28 & 68 & 120 & 60 & 360 \\
\hline & NA & NA & $51 B$ & 25 & 50 & 180 & 70 & 440 \\
\hline \multirow[t]{2}{*}{52} & NA & NA & $52 A$ & 14 & 75 & 130 & 90 & 320 \\
\hline & NA & NA & $52 \mathrm{~B}$ & 17 & 53 & 160 & 90 & 380 \\
\hline 53 & NA & NA & 53 & 20 & 100 & 140 & 70 & 320 \\
\hline $\begin{array}{c}\text { *First-deg } \\
\text { atrioventricl } \\
\text { conduction. } \\
H R=\text { hea } \\
\text { antibody pre }\end{array}$ & $\begin{array}{l}\text { eart } \\
\text { ock fo }\end{array}$ & for a & NA & $\operatorname{lab}$ & $\begin{array}{l}\text { dissociation } \\
\text { ith no } \delta \text { wave } \\
=\text { maternal a }\end{array}$ & junct & $\begin{array}{l}\text { rhythr } \\
\text { anced }\end{array}$ & $\begin{array}{l}\text { ffirst-degree } \\
\text { Ooventricula } \\
=\text { materna }\end{array}$ \\
\hline
\end{tabular}

these values, from that study were used as the normative values in the present study. However, because of the wide range of normal PR intervals at different heart rates and ages (Figures 3 and 4 from Davignon et al), ${ }^{7}$ each PR interval of the subjects in our study was assigned a rank order of 1 to 8 corresponding, in order, to a rank value $<2$ nd percentile (rank value $=1$ ), between the 2 nd and 5th, the 5th and 25th, the 25th and 50th, the 50th and 75th, the 75th and 95th, and the 95th and 98th percentiles, and finally, $>98$ th percentile (rank value $=8$ ). The following 3 analyses were then performed: (1) comparison of the 1982 and 1988 data to determine if the cohorts differed; (2) comparison of all data to examine the effect of onset (before and during vs after pregnancy), as well as other variables; and (3) repetition of analysis 2 using only data from the eldest child to eliminate any intrafamily effects. Tests used to perform these analyses included 1-way analysis of variance model, MannWhitney nonparametric test, chi-square test of independence, and analysis of co-variance and log-linear models. Differences were considered significant if the $p$ value was $\leq 0.05$.

\section{RESULTS}

In this group of 53 women with SLE, serologic results were known for 25 (Table I). A woman was considered as having anti-SSA/Ro antibody if the antibody was found at any time. The rationale for this assumption is based on the reported occurrence of anti-SSA/Ro antibody before the onset of symptoms of $\mathrm{SLE}^{3}$ and because this antibody tends to remain present over prolonged periods of time. ${ }^{8}$ Of these 25 women, most (76\%) were antinuclear antibody positive; $50 \%$ were anti-SSA/Ro antibody positive, and $56 \%$ were antiSSB/La antibody positive. No mother had a child with congenital complete heart block.

The mean age of the offspring studied was $14.5 \pm$ 9.5 years. One-way analysis showed that the 1982 cohort was older $(\mathrm{p}=0.05)$ and, as would thus be expected, had a slower heart rate $(p=0.04)$ than did the 1988 cohort. However, the electrocardiographic intervals did not differ significantly between the 2 groups. SLE was diagnosed before or during pregnancy in 28 cases and after pregnancy in the remaining 58. During 7 pregnancies, the mothers were treated with prednisone. 
Analysis of electrocardiographic data (Table I) showed sinus rhythm in 85 of 86 offspring. A 14-yearold male offspring had both intermittent atrioventricular dissociation and normal sinus rhythm, but normal atrioventricular conduction during sinus rhythm. Serologic data were not available from this subject's mother. One 20-year-old female offspring had right-axis deviation. The PR interval was $<95$ th percentile for age (i.e., normal) in 82 of 86 offspring and $<95$ th percentile for heart rate in 81 . Three children had a PR interval $>95$ th percentile (i.e., first-degree heart block) for both age and heart rate: A 6-month-old male had a PR interval of 0.17 seconds at a heart rate of 136 beats/min, a 6-year-old male had a PR interval of 0.17 second at a heart rate of 100 beats/min, and a 13-year-old male had a PR of 0.18 second at a heart rate of 69 beats/min. Although 2 of the mothers of these 3 subjects developed SLE before or during the pregnancy, all 3 mothers' serum was devoid of anti-SSA/Ro and anti-SSB/La antibody. The PR interval of the other 6 subjects with first-degree heart block for age or heart rate (i.e., $\geq 95$ th percentile) was $\leq 0.18$ second. However, all offspring had intact atrioventricular conduction, and no other isolated electrocardiographic abnormalities were found.

In contrast to the individual data, grouped data suggested subtle effects of maternal SLE on atrioventricular conduction in offspring. Using the aforementioned rank assignment of PR intervals in relation to heart rate and age (and heart rate in relation to age), 2 differences were observed. First, heart rate adjusted for age was significantly $(p=0.003)$ higher in offspring whose mothers had the onset of SLE before or during pregnancy than in the normal population ${ }^{7}$; this difference was not present for children whose mothers developed SLE after pregnancy. Second, PR interval adjusted for heart rate (i.e., rank score indicating a difference in percentile level) was significantly $(\mathrm{p}=0.0001)$ longer (i.e., score was greater) in offspring whose mothers developed SLE before or during pregnancy than in the normal population. ${ }^{7}$ This difference was not present for subjects whose mothers developed SLE after pregnancy. These relations remained when only the eldest child was included in the analysis, supporting the likelihood of a difference related to SLE effects rather than to intrafamily effects. However, the data were insufficient to distinguish between the effects of age and onset of SLE (before and during vs after pregnancy) on PR interval. The analysis examining an antibody effect on PR interval produced no significant results, perhaps owing to a small number of women in whom antibody status was known.

\section{DIscussion}

In these 2 cohorts comprising 86 offspring of 53 mothers with SLE, we detected no isolated, significant, electrocardiographic abnormalities, even in children whose mothers were anti-SSA/Ro antibody positive. First-degree atrioventricular block was detected in 3 offspring; however, the 3 respective mothers were antibody negative during pregnancy, suggesting that in these cases the minor conduction abnormalities were probably unrelated to neonatal SLE. Similarly, the finding of an inter- mittent escape junctional rhythm in 1 adolescent offspring, as well as the right-axis deviation in another, probably represents a normal variant. However, the grouped data suggest that a subclinical effect of maternal SLE may be affecting the fetus and may contribute to a subtle delay in atrioventricular conduction in the fully developed infant or child.

Mechanism of neonatal systemic upus erythematosus: Neonatal SLE syndrome is mediated by the transplacental passage (after the 12th to 16th week of gestation) of maternal immunoglobulin $G$ antibodies to the fetus of a woman with SLE, followed by an immunologically-based inflammatory reaction (and/or deposition) of these antibodies with antigens of the fetal skin and heart, or both. ${ }^{3,5,6,9-14}$ Anti-SSA/Ro and anti-SSB/La antibodies to soluble tissue ribonucleoprotein antigens found in the cytoplasm or nucleus of human cells, or both, ${ }^{10}$ have been proposed as the etiologic agents of congenital complete heart block. ${ }^{11}$ Demonstration of immunofluorescence from antibody deposition in cardiac tissue provides evidence that placentally transmitted immunoglobulin $G$ antibodies may act directly on the heart, producing deposition at the atrioventricular node, central fibrous body and fibrous annulus. ${ }^{15-19}$ Furthermore, Alexander et $\mathrm{a}^{20}$ have demonstrated an antibody (antiSSA/Ro and anti-SSB/La)-mediated inhibition of neonatal rabbit cardiac repolarization, indicating a direct effect on the electrophysiologic properties of developing excitable tissue. All these observations are compatible with a dose-response effect of maternal antibodies on immature atrioventricular conduction tissue.

Risk to fetus: In a retrospective study of offspring of women with SLE, Ramsey-Goldman et $\mathrm{al}^{6}$ described 16 infants with congenital complete heart block in 96 pregnancies of women who had anti-SSA/Ro antibody. In contrast, only 1 infant in 235 pregnancies of women with SLE but without anti-SSA/Ro antibody had neonatal SLE. In that study, the overall risk of a woman with SLE having an infant with congenital complete heart block was estimated to be 1:60 (when corrected for referral bias), but the risk was considerably greater (1:20) if anti-SSA/Ro antibody was present. Buyon et $\mathrm{al}^{21}$ have described maternal antibodies from the mothers of neonatal SLE infants to specific peptides of the ribonuclear SSA/Ro complex, as well as to the SSB/La particle; both of these peptides are abundant in fetal cardiac tissues. The presence of antibodies to these specific peptides increases the risk ratio of a mother with SLE giving birth to an infant with neonatal lupus by a factor of 35 .

Clinical implications: The incidence, reduced morbidity and improved survival of women of childbearing age affected by SLE renders pregnancy in these cases an important clinical problem. This study was retrospective. Thus, transient conduction disturbances in the neonatal period may have been overlooked. However, the study underscores the strong possibility of subclinical alterations in atrioventricular conduction in some fetuses exposed to a maternal SLE environment, and thus supports a dose-response relation between atrioventricular conduction in the fetus and infant and maternal SLE 
antibodies. However, because of bradycardia noted in the newborn at birth, congenital high-grade or complete heart block is usually recognized and confirmed by electrocardiography. Thus, if the heart rate of a fetus or newbom whose mother has SLE is normal, neither early obstetric intervention nor routine postnatal electrocardiograms are necessary.

Acknowledgment: We wish to acknowledge and extend our thanks to MaryBeth Landrum and Morton Brown for statistical advice and support.

\section{REFERENCES}

1. Esscher E, Scott JS. Congenital heart block and maternal systemic lupus erythematosus. Br Med J 1979;1:1235-1238.

2. McCue CM, Mantakas ME, Tingelstad JB, Ruddy S. Congenital heart block in newborns of mothers with connective tissue disease. Circulation 1977;56:82-90.

3. Scott JS, Maddison PJ, Taylor PV, Esscher E, Scott O, Skinner RP. Connective-tissue disease, antibodies to ribonucleoprotein, and congenital heart block. $N$ Engl J Med 1983;309:209-212.

4. Nolan RJ, Shulman ST, Victorica BE. Congenital complete heart block associated with matemal mixed connective tissue disease. J Pediatr 1979;95:420-422.

5. Chameides L, Truex RC, Vetter V, Rashkind WJ, Galioto FM, Noonan J $\Lambda$. Association of matemal SLE with congenital complete heart block. $N$ Engl J Med 1977;297:1204-1207.

6. Ramsey-Goldman R, Hom D, Deng JS, Ziegler GC, Kahl LE, Steen VD, LaPorte RE, Medsger TA. Anti-SS-A antibodies and fetal outcome in matemal systemic lupus erythematosus. Arthritis Rheum 1986;29;10:1269-1273.

7. Davignon A, Rautaharju P, Boisselle E, Soumis F, Megelas M, Choquette A Normal electrocardiogram standards for infants and children. Pediatr Cardio $1979 / 1980 ; 1: 123-131$

8. Wasicek CA, Reichlin M. Clinical and serological differences between system- ic lupus erythematosus patients with antibodies to Ro versus patients with antibodies to Ro and La. $J$ Clin Invest 1982;69:835-843.

9. Provost TT, Watson R, Gammon WR, Radowsky M, Harley JB, Reichlin M The neonatal lupus syndrome associated with $\mathrm{U}_{1} \mathrm{RNP}$ (nRNP) antibodies. $N$ Engl $J$ Med 1987;316;18:1135-1138.

10. Kraft JE, Hardin JA. Linked sets of antinuclear antibodies: what do they mean? $J$ Rheumatol 1987;14(suppl 13):106-109.

11. Harley JB, Kaine JL, Fox OF, Reichlin M, Gnuber B. Ro(SS-A) antibody and antigen in a patient with congenital complete heart block. Arthritis Rheum 1985;28:1321-1325.

12. Harmon CE, Lee LA, Huff JC, Norris DA, Weston WL. The frequency of antibodies to the SS-A/Ro antigen in pregnancy sera (abstr). Arthritis Rheum 1984; 27:S20.

13. Deng JS, Sontheimer RD, Giliam JN. Molecular characteristics of SS-B/La and SS-A/Ro cellular antigens. $J$ Invest Dermatol 1985;84:86-90.

14. Kephart DC, Hood AF, Provost TT. Neonatal lupus erythematosus: new serologic findings. $J$ Invest Dermatol 1981;77:331-333.

15. Taylor PV, Scott JS, Gerlis LM, Esscher E, Scott O. Maternal antibodies against fetal cardiac antigens in congenital complete heart block. $N$ Engl J Med 1986; 315:667-672

16. Ishibashi-Ueda $H$, Yutani C, Imakita $M$, Kanzaki T, Utsu M, Chiba Y. An autopsy case of congenital complete heart block in a newly born of a mother with systemic lupus erythematosus. Pediatr Cardiol 1988;9:157-161.

17. Lee LA, Coulter S, Erner S, Chu H. Cardiac immunoglobulin deposition in congenital heart block associated with maternal anti-Ro autoantibodies. Am J Med 1987;83:793-796

18. Olson NY, Lindsley CB. Neonatal lupus syndrome. Am J Dis Child 1987; 141:908-910.

19. Litsey SE, Noonan JA, O'Connor WN, Cottrill CM, Mitchell B. Maternal connective tissue disease and congenital heart block. Demonstration of immunoglobulin in cardiac tissue. $N$ Engl $J$ Med 1985;312:98-100.

20. Alexander EL, Buyon JP, Lane J, Lafond-Walker A, Provost TT, Guarnier T. Anti-SSA/Ro SSB/La antibodies bind to neonatal rabbit cardiac cells and preferentially inhibit in vitro cardiac repolarization. $J$ Autoimmun 1989:2:463-469.

21. Buyon JP, Ben-Chetrit E, Karp S, Roubey RAS, Pompeno L, Reeves WH, Tan EM, Winchester R. Acquired congenital heart block. Pattern of maternal antibody response to biochemically defined antigens of the SSA/Ro-SSB/La system in neonatal lupus. J Clin Invest 1989:84:627-634. 